\title{
Egy nagyszabású rendezvény hatása a rossz városimázsra: Ferenc pápa látogatásának befolyása Juarez város megítélésére
}

\author{
Szerzők: Irigoyen Carlos Omar ${ }^{1}$ - Neulinger Ágnes² - Molnár-Csomós Ilona ${ }^{3}$
}

A tanulmány célja, hogy egy negatív megitélésú város példáján keresztül mutassa be a városimázs javitásának lehetôségeit. Ehhez a pápalátogatás nagyszabású rendezvényének lehetséges imázsjavító hatásait elemeztük a mexikói Juarez város példáján keresztül. Az elméleti áttekintés részeként bemutatjuk a városmarketing és városmárkázás fogalmait, majd az Anholt-féle városmárka hatszög segítségével értelmezzük Juarez helyzetét. A pápalátogatás szerepét online turisztikai oldalak és online médiatartalmak segítségével elemeztük és megállapítottuk, hogy az esemény médiafigyelme és pozitív üzenete megadta a lehetôséget a város megitélésének javítására, azonban a külsó adottságok, a mélyben rejlô strukturális problémák nem tették lehetôvé ennek kiaknázását.

Kulcsszavak: városmarketing, városmárkázás, pápa látogatása.

\section{Bevezetés}

A mexikói Juarez városa több okból is ellenszenves helynek számított, amelyek elsősorban a búnözéshez, a gazdasági visszaeséshez és a barátságtalan turisztikai környezethez kapcsolódtak. A nemzetközi sajtó által kialakított negatív imázs még a határmenti lakosok számára is elkerülendóvé tette a várost. Mindezek arra ösztönözték Juarez vezetőit, hogy megkeressék annak a módját, hogyan tegyék vonzóbbá a várost mind a turisták, mind az ott lakók számára. A városmarketing többek között az infrastruktúrán, a hely múltján és kulturális örökségén, a kínált szolgáltatásokon, a gazdasági lehetőségeken - de minden esetben olyan kézzelfogható értékeken - alapszik, amelyeket egy város kínálhat az érintettek számára. Kérdés ugyanakkor, ha ezek alapvetóen nem vonzóak, marad-e más lehetôség, amely egy hely megítélését pozitívabbá teheti? A jelenlegi elméletek a város, mint élóhely számos jellemzôjére fókuszálnak, de kevés a szakirodalomban az a megközelítés, amely egy esemény vagy megkülönböztetett figyelmet érdemlô személy látogatásának a hatását vizsgálja az adott hely megítélésére vonatkozóan.

Ferenc pápa egyike a világ legbefolyásosabb személyiségeinek és a Szent Atya Juarezben tett

\footnotetext{
${ }^{1}$ PhD-hallgató, Budapesti Corvinus Egyetem, iricarlos@gmail.com

2 egyetemi docens, Budapesti Corvinus Egyetem,

agnes.neulinger@uni-corvinus.hu

${ }^{3}$ PhD-hallgató, Budapesti Corvinus Egyetem, ilona.csomos@uni-corvinus.hu
}

2016-os látogatása a város történelmének egyik legérdekesebb eseménye volt. Vajon egy olyan ember, aki ekkora befolyással rendelkezik, meghatározó hatással lehet a város imázsára? Korábbi kutatások alapján a nagyszabású események kedvező hatást fejthetnek ki az érintett városok megitélésére (RICHARDS-WILSON 2004), igaz ezek befolyása nem minden esetben tudott érvényesülni (ZHANG-ZHAO 2009). Kérdéses továbbá, hogy ez a remélt pozitív befolyás miként tud érvényesülni egy olyan hely esetében, amely erôsen kedvezőtlen helyzetben van. Lehetséges, hogy Ferenc pápa juarezi látogatása katalizátorként szolgál a hely átformálását célzó márkaépítés és így a városmarketing programok terén, vagy mindez csak elszigetelt eseményként értelmezhetó, amelynek nincs kiterjedtebb hatása? Jelen cikk célja, hogy a városmárkázás nézôpontjából vizsgálja meg a pápalátogatás jelentőségét egy negatív megítélésú város esetében. Cikkünk elsố része kitér a városmárkázás, valamint a városmarketing témaköreire. A szakirodalmi áttekintés során olyan elméleti keretek és koncepciók kerülnek bemutatásra, amelyek alkalmasak arra, hogy azokon keresztül megértsük egy meghatározó személy befolyását egy város imázsára egy hátrányos helyzetú lokáció kontextusában. Ezt követően a látogatást megelőző és követő időszakok sajtó megjelenései alapján értékeljük, hogy a vizsgált esetben milyen visszhangot váltott ki Ferenc pápa látogatása.

A pápalátogatás elemzése lehetôséget ad annak megértésére, hogy egy széleskörben elfogadott és jelentős, erôs érzelmi kötődést kifejező esemény milyen imázs következménnyel járhat a 
helyszínként érintett város esetében. A pápalátogatás egy olyan mega esemény, amelyet jellemzően nagyobb elfogadás kísér, mint bámely más nagyszabású rendezvényt (jellemzően sporteseményt). Közvéleménykutatások szerint a brazil olimpiai játékok megrendezését a lakosság fele ellenezte (NEW YORK TIMES 2016), és Calgary téli olimpia rendezése kapcsán is hasonlóan magas (55\%) volt az ellenzők aránya (CBC 2018). Ezzel szemben a pápa egyesült államokbeli látogatását mindössze a teljes lakosság 11\%-a utasította el, miközben támogatása a hívők körében átlag feletti volt (IPSOS MORI 2010). Ilyen adat a mexikói eset kapcsán nem áll rendelkezésre, de a régió hagyományosan erős katolikus területein hasonlóan magas elfogadási arány vélelmezhetô. Emellett a tanulmány sajátossága, hogy egy olyan rendezvény lehetséges hatását elemzi, amelynek szimbolikus jelentése (szentség, béke, remény) közvetlenül támogatja az érintett város imázsjavítási törekvéseit.

\section{Városmarketing és városmárkázás}

\subsection{ELMÉLETI HÁTTÉR}

A marketing, az egyik legnépszerúbb meghatározása szerint, olyan eljárást jelent, „amelynek segítségével egyének és csoportok termékeket és értékeket alkotnak és cserélnek egymás között, miközben szükségleteiket és igényeiket kielégitik" (KOTLER 2002:39). Ez a megközelítés régiók és települések vonatkozásában is ér- telmezhető, amelynek kapcsán olyan fogalmak születtek a régió- és településmarketing területén, mint a városok promóciója, a városmarketing, a desztinációmárkázás, illetve a régió- és településmárkázás. A marketing elméleti fogalmi keretét azonban nem lehet egyszerúen lefordítani lokációk (és annak valamely szintjének, úgymint ország, régió, település, kerület, legszúkebb múködési területe) esetére, hiszen vannak olyan speciális jellemzők, amelyek csak adott szintnél jelentkeznek (RIEZEBOS 2009). Eszerint a marketing klasszikus 4P megközelítése helyett valami másra van szükség, amely ugyanúgy kifejezi annak lényegét, mégis alkalmazkodik a lokációk adottságaihoz. ASHWORTH és VOOGD (1990) az úgynevezett geográfiai marketingmix részeként négy elemet említ, amelyek (1) a promóciós jellemzók, (2) a terület funkcionális elemei, (3) a szervezeti jellemzók és (4) a pénzügyi jellemzók. Megközelítésük szerint ezen elemek megfelelő kiválasztása és alkalmazása nagymértékben befolyásolja a városmarketing tevékenységek sikerét. PISKÓTI (2012) 2K-t javasol a 4P helyett, azaz megkülönbözteti a kínálati mixet (beleértve és együttesen kezelve a régió, illetve település termékét és árát), valamint a kommunikációs mixet (magába foglalva a kommunikáció és a disztribúció együttesét).

KAVARATZIS (2007) a városmarketing kialakítása kapcsán öt tevékenységet értelmez, nevezetesen (1) a lokáció aktuális helyzetének - beleértve a tulajdonait, lehetőségeit és közönségét - elemzését, (2) az érintettekkel közösen kialakított, majd

„Kinek mi a fontos az országképböl?"

\section{ORSZÁGMÁRKA ELEMEI}

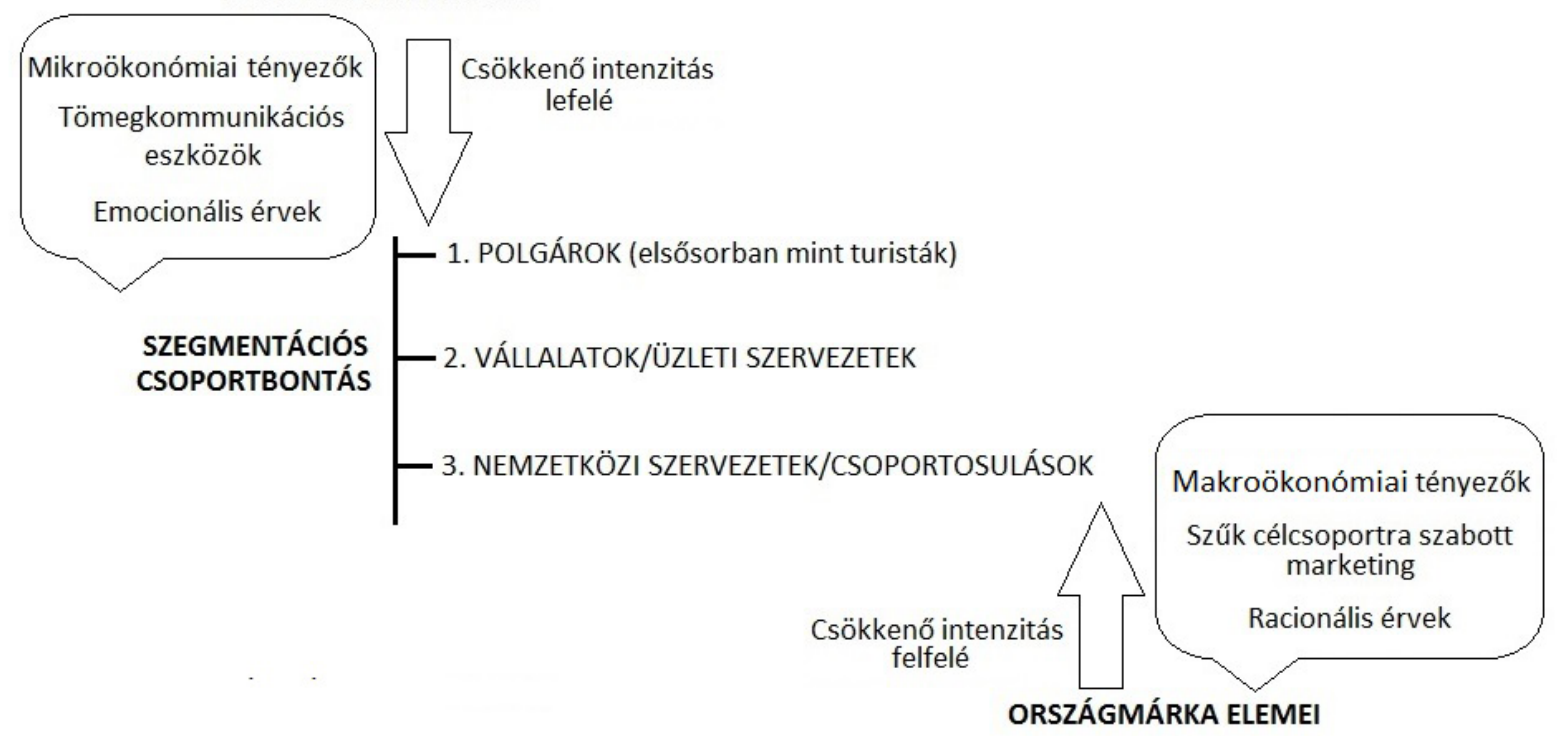

Forrás: MOLNÁR-CSOMÓS (2017:13) szerkesztése PAPP-VÁRY (2006:6) és GYŐRI (1998:47) alapján 
Lektorált tanulmányok

kommunikált víziót, (3) a stratégiai terv kidolgozása során az összes érintett felelősségének meghatározását a célok elérése érdekében, (4) a terv végrehajtását, (5) az eredmények nyomon követését és értékelését, valamint a tapasztalatok megfogalmazását. GREENBERG (2000:230) a városmárkázás egyik központi elemének az áruvá vált városok és az egyre szabadabb - így lazábban kötődó - közép- és felsóosztályba tartozó fogyasztók közötti érzelmi kapcsolódás kialakulását tartja, hogy „már maga a város neve egy sor képet, érzelmet és ehhez kapcsolódóan az értékességet idézzen fel".

A városmarketing és városmárkázás fogalmai között fennálló kapcsolat jól látható. A városmarketing a város imázsának, kommunikációjának, illetve a lakosok tapasztalatainak, észlelésének és érzéseinek az eredménye. Az ezekból a tapasztalatokból származó mentális térképek adják a városmárkázás alapjait, amit a város marketingprogramjai megerősíthetnek vagy éppen eltorzíthatnak (KAVARATZISASHWORTH 2005). Összességében a városmarketing olyan immateriális jellegú és kézzelfogható tevékenységek kombinációja, amely vonzóbbá és versenyképesebbé teheti a várost. A városmárkázás pedig az a folyamat, amely képes azonosítani, felépíteni és kommunikálni a város tulajdonságait a lakosság és a helyszín közötti releváns kapcsolatok megteremtése és megtartása érdekében (RAMOS 2011).

A városmárkázás témaköréhez szorosan kapcsolódó országmárkázásra is szükséges kitérni, lévén, hogy "a jövôben egyetlen ország sem kerülheti ki a márkázást, ha helyt akar állni a versenyben" (PAPP-VÁRY 2006:2). Országimázs-építéskor javallott a szegmentálást az országmárkázási célkitúzések szempontjából megközelíteni. Ez alapján három csoport képezhetó. Az 1. ábra - a csoportok felsorolása mellett - azt mutatja be, hogy az adott csoportba tartozó egyének számára melyik országmárkázó elem, milyen intenzitással fontos.

Csoportképző ismérvek:

- Polgárok (elsősorban, mint turisták):

- számukra egy vásárlói döntéssel azonos, hogy felkeresnek-e egy országot, vásárolják-e a termékeit;

- nem statisztikai szemüvegen át tekintenek az adott országra;

- nagy szerepe van az emóciónak (csak speciális esetben kerülnek előtérbe a racionális érvek, mint például diákként az Erasmus program keretében).

- Vállalatok/üzleti szervezetek:

- adott országgal kereskedelmi kapcsolatban állnak;
- mikroökonómiai környezetben tevékenykednek, mindemellett a makroökonómiai környezet is hat rájuk, múködési kereteiket is ez határozza meg.

- Nemzetközi szervezetek/csoportosulások:

- szigorúan vett makroökonómiai szempontrendszer alkalmazása az adott ország górcső alá vételekor;

- fóképp a racionális érvek a mérvadók (döntéshozói szinten bizonyos esetekben emocionális érvek is megjelennek).

Összességében elmondható, hogy mindhárom csoportnak ugyanazt lehet és kell is kommunikálni, a lényeg csupán annyi, hogy mindezt az adott csoport számára legmegfelelőbb módon tegyük, OLINS (2001) megközelítését követve "nem teljesen mást mondva, hanem ugyanazt egy kicsit másként megfogalmazva".

Juarezben a város megítélésének javítására számos kezdeményezés indult el a közelmúltban, elsósorban a fenti első kettő érintetti csoportot megcélozva, amelyek a pozitív városkép kialakítását, és az érzelmi kapcsolat megteremtését célozták. Azonban az elindult marketingkampányok, úgymint a Sientete orgulloso de Juarez (Büszke lehet Juarezre), a Grupo Jrz (Juarez Csoport), a Juarez es amor (Juarez a szerelem) vagy a kormány internetes oldalának fejlesztése, csak elszigetelt erőfeszítések voltak a helyi önkormányzat vagy a város részéről, amelyek nem voltak képesek arra, hogy erós és pozitív képet alakítsanak ki a városról. SARTORI és szerzőtársai (2012) szerint a siker akkor érhetó el, ha közös az erőfeszítés a város érintettjei részéról, és a városvezetés hatékony belső kommunikációt folytat a bevonásukra és elköteleződésükre. Eszerint a kommunikációnak ki kell térnie az összes szereplőre, úgymint a város vezetése, a lakók, a helyi vállalkozások és a turisták (HERSTEIN et al. 2013). Az együttmúködés és közös felelősség fontosságát erősíti meg VAN GELDER (2008:1), aki szerint a hatékony városmárkázás "a vezetés, a stratégia és a kreativitás új formáit igényli". Ezzel kapcsolatban a dán Høje-Taastrup község városmárkázási stratégiai dokumentuma (HOJE-TAASTRUP KOMMUNE 2010:4) egy hely márkázására vonatkozóan megjegyzi, hogy azzal „sokféle lakosnak és látogatónak tudnia kell azonosulni". FAN (2006) mindezt a nemzeti márka jelentőségének hangsúlyozásával egészíti ki, amely egy országon belül az egyes lokációk megítélésére is meghatározó lehet. Ennek megfelelően a település márkázása kapcsolódhat nemzethez és országhoz olyan helyszínek esetében, amelyeknek nemzetközi szinten is relevánsan megfogalmazható céljai vannak (például munkalehetóség, befektetés, 
nyugdíjasok letelepedési célú elérése vagy mint nyaralási helyszín). Ezek a városfejlesztési politikák számára is hasznosak és hozzájárulhatnak a versenyképesség eléréséhez (HOSPERS 2010).

A városmarketing és városmárkázás számos kihívással néz szembe. OOI (2013) szerint ezek egyrészt a választott üzenet (pozícionálás, kommunikáció) hitelességéhez, másrészt a nagyon különböző célcsoportokhoz (érintetti körökhöz) kapcsolódnak. Tekintettel arra, hogy a márkát a hely pozitív aspektusaira építik, ez minden olyan lokáció számára, amely negatív megítéléssel rendelkezik - úgymint Juarez városa - különösen nehézzé teszi a sikeres marketing- és márkázási tevékenység folytatását. A továbbiakban egy olyan elméleti megközelítést mutatunk be, amely alkalmas keretet adhat Juarez város helyzetének értékeléséhez.

\subsection{AZ ANHOLT-FÉLE VÁROSMÁRKA HATSZÖG}

Az Anholt-féle városmárka koncepció hatékony eszköznek bizonyulhat Juarez aktuális városképének értelmezéséhez. Az ANHOLT (2006) által kialakított városmárka index (hatszög) elemei (6P) a következôk (2. ábra):

- Jelenlét (presence): a város ismertsége és megítélésének jellemzői, amelyek SCHEEL és PINEDA (2014) szerint alkalmasak arra, hogy a város kedvezó imázsa esetén új lakókat és üzleti befektetőket vonzzanak.

- Hely (place): a hely fizikai jellemzóit foglalja magában, úgymint a város szépsége, rendezettsége, időjárási viszonyai, így jelzi, hogy mennyire kellemes a városban lenni.

- Előfeltételek (pre-requisites): a városi szolgáltatásokat (például szálláshely, közszolgáltatások) foglalja magában, amely az összes érintett, így a lakók és látogatók életminőségét is érintheti (PAPP-VÁRY 2011).

- Emberek (people): a lakók kedvességét, nyitottságát és befogadóképességét, a közösség jellemzőit foglalja magában. Az emberek különösen fontosak a város imázsának kialakításában, így bevonásuk a városmarketing projektekbe kulcsfontosságú azok legitimitásának eléréséhez (BRAUN et al. 2013).

- Pulzus (pulse): a város érdekessége, izgalmassága, amely utal az elérhető programok és szabadidős tevékenységek sokszínúségére.

- Potenciál (potential): A gazdasági és oktatási lehetôségeket foglalja magában, amelyek nemcsak az emberek észlelésében, hanem az eredeti koncepciót továbbgondolva objektív mutatókban is kifejeződhetnek, úgymint munkanélküliségi ráta, vásárlóerő, bérszínvonal, oktatási infrastruktúra. Ezek alkalmasak lehetnek arra, hogy a városba vonzzák a sok- szor valamely tudásintenzív ágazatban dolgozó, úgynevezett kreatív osztály (FLORIDA 2014) tagjait.

2. ábra

ANHOLT városmárka hexagon megközelítése

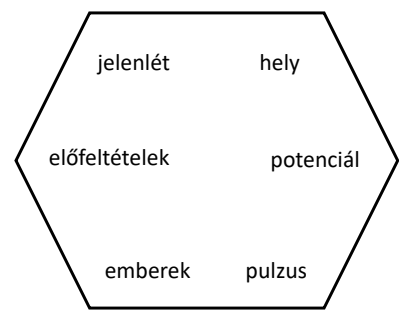

Forrás: saját szerkesztés ANHOLT (2006:19) alapján

Amennyiben az Anholt által javasolt szempontokat Juarez városára értelmezzük, akkor a hat szempontból kettő tekinthetô megfelelő színvonalúnak, míg négy fejlesztendőnek (PLAN ESTRATÉGICO DE CIUDAD JUÁREZ 2016). A város megítélésének (jelenlét) elsődleges problémáit az erôszak, a korrupció és a szegénység magyarázza, de problémákat okoz a kábítószer-függőséggel élők nagy száma, az alapvetố szolgáltatások hiánya, a gazdasági válság negatív következményei (például elbocsátások) és a gyenge tömegközlekedés is. Mindezek a társadalmi elhalás közvetlen okai lehetnek hosszú távon. Ezzel együtt a városban élő lakosság fele hálás azért, hogy itt élhet, és többségük nem fontolgatja a város elhagyását. További fejlesztendő terület a hely fizikai megjelenése (hely), a városi szolgáltatások színvonala (előfeltételek), illetve a gazdasági és oktatási lehetôségek (potenciál). A részletes értékelést lásd az 1. táblázatban.

\section{Ferenc pápa látogatásának jelentốsége Juarez városa számára}

\subsection{JUAREZ ADOTTSÁGAI, TÖRTÉNELMI MEGHATÁROZOTTSÁGA}

Az Egyesült Államokkal határos Chihuahua északi részén fekvő várost 1659. december 8-án alapította meg Fray Garcia de San Francisco "The Mission of Our Lady of Guadalupe de los Mansos of the Paso del Norte" néven (DURAN 2014). A hely bevándorlási helyszín volt, amolyan természetes átkelőhely a spanyol hódítók számára (REYNOLDS 2011). 1848. február 2-án Mexikó és az USA aláírta a GuadalupeHidalgo megállapodást, így Paso Del Norte határvidékké vált, majd 1885-től 1891-ig Porfirio Diaz elnök döntése nyomán vámmentes zóna volt. 1888. július 30-án Paso del Norte városa Juarez Cityre változtatta a nevét a volt mexikói elnök, Benito 
Lektorált tanulmányok

\section{Juarez város értékelése az Anholt-féle városmárka hatszög szerint}

\begin{tabular}{|c|c|c|c|}
\hline Kritériumok & Szempont & Juarez jellemzői & Minősítés \\
\hline Jelenlét & $\begin{array}{l}\text { A város } \\
\text { ismeretel } \\
\text { megítélése }\end{array}$ & $\begin{array}{l}\text { A lakosság 56,6\%-a hálás azért, hogy Juarezben élhet, 69,2\%-uk még } \\
\text { sosem gondolt arra a lehetôségre, hogy elhagyja a várost. A boldogság } \\
\text { index a mexikói átlag körül alakul, a wellness index tekintetében pedig a } \\
\text { 20. helyet foglalja el Mexikó } 20 \text { legnépesebb városa közül. Ugyanakkor } \\
\text { a város külsố megítélése kritikus: a város problémáinak } 80 \% \text {-át néhány } \\
\text { kulcstényezô magyarázza, ezen belül az erőszak, a korrupció és a szegénység a } \\
\text { legfontosabbak, a problémák } 46 \% \text {-a ezekből tevódik össze. }\end{array}$ & Fejlesztendő \\
\hline Hely & $\begin{array}{l}\text { A város } \\
\text { fizikai } \\
\text { feltételei, } \\
\text { szépsége }\end{array}$ & $\begin{array}{l}\text { Juarez városa a legnépesebb Chihuahua államban. A város a Chihuahua-sivatag } \\
\text { területén fekszik, a Rio Bravo del Norte partján. Ennek megfelelöen éghajlata } \\
\text { sivatagos, az éves csapadékmennyiség alacsony. Számos természeti szépséggel } \\
\text { rendelkezik, amelyet az ipari részek jelenléte és túlzott fejlesztése elront. }\end{array}$ & Fejlesztendő \\
\hline Elöfeltételek & $\begin{array}{c}\text { Városi } \\
\text { szolgáltatások }\end{array}$ & $\begin{array}{l}\text { A város növekedése nem jól tervezett, } 10 \text { év leforgása alatt több mint } \\
\text { tízszeresére nött a terület a lakossághoz képest. Ez súlyos diszperziós } \\
\text { állapotot jelez és ezen körülmények mellett a közszolgáltatások nyújtásának } \\
\text { hatékonysága nehezebben biztositható. }\end{array}$ & Fejlesztendő \\
\hline Emberek & $\begin{array}{l}\text { Az emberek } \\
\text { jellemvonása } \\
\text { a helyszínen }\end{array}$ & $\begin{array}{l}\text { Az emberek nyitott gondolkodásúak, a lakosságnak összesen } 11,2 \% \text {-a vált } \\
\text { diszkrimináció áldozatává. A diszkrimináció három legfontosabb oka az } \\
\text { életkor, a fizikai megjelenés és a születési hely. A megkülönböztetés további } \\
\text { okai - úgymint társadalmi osztály, szexuális irányultság, vallás vagy politikai } \\
\text { preferenciák - kisebb mértékben (mind 5\% alatt) érintik a lakosságot. }\end{array}$ & Megfeleló \\
\hline Pulzus & $\begin{array}{l}\text { A város } \\
\text { érdekessége, } \\
\text { izgalmassága }\end{array}$ & $\begin{array}{l}\text { Juarez a bevásárlóközpontjairól ismert. A szabadidô eltöltése javarészt a } \\
\text { bevásárlóközpontokban történik, a lakosság 70,2\%-a itt tölti el szabadidejét. } \\
\text { A városban található egyéb érdekes tevékenységek közé sorolandó a moziba, } \\
\text { bárokba, koncertekre járás, valamint a nyilvános parkok, természeti parkok, } \\
\text { szórakoztató parkok, vásárok, sportesemények látogatása. }\end{array}$ & Megfelelő \\
\hline Potenciál & $\begin{array}{l}\text { Gazdasági } \\
\text { és oktatási } \\
\text { potenciál }\end{array}$ & $\begin{array}{l}\text { Alacsony a lemorzsolódás az általános és középiskolában. Alacsony a } \\
\text { munkanélküliségi ráta, de a fizetések is, amelyek így nem teszik lehetôvé az } \\
\text { életminôség javítását. A szakmunka aránya magas, a tudásintezív ágazatok } \\
\text { jelenléte alacsony. }\end{array}$ & Fejlesztendő \\
\hline
\end{tabular}

Forrás: saját szerkesztés a PLAN ESTRATÉGICO DE CIUDAD JUÁREZ (2016) statisztikái alapján

Juarez tiszteletére. A második világháborút követően Juarez gazdasági megújulásának alapját a Juarez sugárúton ${ }^{4}$, a Santa Fe Nemzetközi Híd körül található éttermek, kabarék, báltermek adták. Ebben az időben Jurez életében meghatározó iparág volt a turizmus, és a pezsgó éjszakai életnek köszönhetően figyelemre méltó híres sztárok - mint például Frank Sinatra, Elizabeth Taylor és Steve McQueen - gyakran bukkantak fel a városban (MARTÍNEZ 2004).

Az 1964-es évet követően Gustavo Diaz Ordaz elnök új gazdaságstratégiai megoldásként bevezette a Maquiladora programot, amelynek célja a szórakoztatóipar háttérbe szorítása, valamint egy új gazdasági modell megvalósításának előkészítése volt. Az új modell elsődlegesen azon nagyvállalatok bevonzását jelentette, amelyeknek fő tevékenységei közé az alkatrészek, autók, mobiltelefonok,

\footnotetext{
${ }^{4}$ A Santa Fe híd melletti sugárút azon amerikaiak körében volt igazán nép szerű, akik ezt az utat a szórakozási lehetőségekkel vonták párhuzamba.
}

orvosi felszerelések, ruházat, elektronikai, számítástechnikai valamint kommunikációs alkatrészek gyártása, illetve ezeknek a termékeknek az érintett nagyvállalatok anyaországába történó exportálása tartozott. Az így létrejött új munkalehetőségek több bevándorlási hullám ösztönzői voltak: 1989-ben Torreonból, Gomez Palacio és Zacatecasból, 1990-ben Veracruzból, 2000 után Oaxacából, Chiapasból, Guerrero-ból és Michoacanból számos bevándorló érkezett A bevándorlókat elsődlegesen a jobb életszínvonal megteremtése, az "amerikai álom" elérése vezette. Mindeközben a gazdasági fejlődés egyre jobban elszakadt a társadalmi fejlődéstől, a város életében a kereskedelem és ipar húzó szerepe kiegyensúlyozatlan állapotot idézett eló, és egyre több probléma jelent meg a fentebb már ismertetettek szerint (MARTÍNEZ 2004). Mindezek miatt Juarez egyre inkább hátrányos helyzetú várossá vált. 
Lektorált tanulmányok

\subsection{A PÁPALÁTOGATÁS HÁTTERÉNEK BEMUTATÁSA}

2014 májusában küldött elóször levelet Juarez püspöke, Jose Guadalupe Torres, a Vatikánnak, amelyben felkérte Ferenc pápát, hogy látogassa meg Juarezt. Kérését azonban visszautasították. Késóbb, 2015 nyarán, az önkormányzat újabb erôfeszítéseket tett arra vonatkozóan, hogy felkeltse Ferenc pápa érdeklődését a város iránt, a válasz azonban annyi volt, hogy Mexikó meglátogatása esetén Juarez is megfontolás tárgyává válik. Amikor 2015 végén a mexikói püspökséget értesítették a 2016-os lelkipásztori útról, egyben jelezték azt is, hogy Juarez is része lesz a helyszíneknek. A hivatalos bejelentés előtt Hesiquio Trevizo, Juarez egyházmegye szóvivője, így nyilatkozott ${ }^{5}$. Ferenc pápa Juarezbe történô esetleges látogatása sok mindent jelentene, nemcsak a város szintjén, hanem világviszonylatban is, mert ilyenkor az egész világhoz szól. Városunknak komoly kihívásokkal kell szembenéznie... ott van az erôszak, a bevándorlók rettenetes világa, a gyermekekkel szembeni visszaélés és hasonló dolgok". A beszéd reflektált Juarez kihívásaira, így ismert helyi problémák jelentek meg benne, úgymint a szociális egészség, a személy méltósága, az erőszak köre, a család társadalmi szerepe, a jó társadalmi rehabilitációs rendszerek szükségessége, a korrupt gyakorlatok megállítására irányuló sürgős fellépés és a legmegfelelóbb megoldás ezeknek a problémáknak a megelőzésére (ACI PRENSA VATICANA 2016).

2016. február 17-én Ferenc pápa öt helyszínt érintve meglátogatta Juarez városát. A látogatás helyszínei a következők voltak: a reptér, a börtön, a papnevelő intézet, a korábbi vásártér és egy középiskola. A pápa a Colegio de Bachilleres ${ }^{6}$ középiskolában tartott beszédében Juarezzel kapcsolatos vízióját is megfogalmazta, kiemelve az oktatási lehetôségek és a jövedelmező munkahelyek fontosságát, amelyek lehetóvé teszik a fiatalok számára, hogy jó életminőségben részesüljenek. A jelenlegi állapotokat jelzô szegénységgel és marginalizálódással szemben az egyházfő a helyreállítás és fejlesztés sürgősségét hangsúlyozta. Mivel Juarez lényegében bevándorlási pontot jelent, a pápa beszéde emlékeztetett arra, hogy a migráció, mint globális jelenség, fontos és alapvetó kérdéseket vet fel, amelyek érintik az emberi kizsákmányolás, az emberrablás, a szétszakadt családok és egyének sorsának témáit (ACI PRENSA VATICANA 2016).

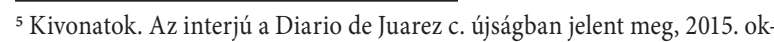
tóber 15-én.

${ }^{6}$ A Colegio de Bachilleres Juarez legismertebb középiskolája.
}

\subsection{A PÁPALÁTOGATÁS LEHETSÉGES HATÁSAINAK BEMUTATÁSA}

\subsubsection{Az elemzés módszertani háttere}

Elemzésünkben két típusú adatforrást vizsgáltunk, egyrészt az utazási portálokon megtalálható lakossági véleményt mutató bejegyzéseket, másrészt a Juarezre vonatkozó online sajtóhíreket és elemzéseket. Mindkét esetben csak azokat, amelyek angolul jelentek meg. Más adatforrás nem állt az elemzés rendelkezésére, amely egyúttal a kutatás korlátját is jelenti. A lakossági vélemények mindegyike a pápalátogatást követő időszakból származik és 2016 novembere és 2017 augusztusa között jelent meg. A vizsgált időszakban összesen négy beszélgetés indult Juarez városa és annak biztonsága kapcsán, melyek összesen 15 hozzászólást generáltak a Tripadvisor, a Lonelyplanet és a Quora felületén. Az online sajtómegjelenések öszszesen 24 különbözó hírcsatornából származnak, beleértve a helyi, a regionális és a globális médiumokat ${ }^{7}$. A hírek két időszakból származnak, egyrészt a pápalátogatást közvetlenül megelőző és az az alatti időszakból, másrészt a pápalátogatást követó 2016 szeptembere és 2018 júniusa közti időszakból. Összesen 29 online médiahírt és elemzést vizsgáltunk, amelyek egy része folytatólagos hírfolyamból és hosszú helyzetértékelésból állt, így a vizsgált adatmennyiség összesen 80 írott oldalt tett ki. Ennél jelentősen rövidebbek voltak az utazási portálokon közzétett vélemények, melyek összesen 11 írott oldalt tettek ki.

Figyelembe véve az elemzett források menynyiségét és sokszínúségét, az elemzés kvalitatív, amely tekintettel van a forrás jellegére és a megjelenés idópontjára. Kvantitatív elemzést nem végeztünk, mert az áttekintett anyagok csak minták feltárására voltak alkalmasak, arra nem, hogy valamilyen egységes bázison arányokat és mennyiségeket közöljünk.

\subsubsection{Középpontban a közbiztonság}

Juarez megítélése a vizsgált források alapján egyértelmú, egy irányba mutató. Az egyes hírforrások háttere (fóleg a helyi vagy globális jelleg, a múfaj és a politikai irányultság) természetesen befolyásolta a megrajzolt kép árnyalatait, a vélemények mégis hasonló irányba mutatnak.

\footnotetext{
${ }^{7} \mathrm{Az}$ elemzésbe bevont online hírforrások listája betürendben: $\mathrm{ABC}, \mathrm{Al}-$ buquerque Journal, Americas Voice, BBC, Boston College News, Business Insider, CBS4, Cronekite News (Arizona), El Pais, El Paso Herald Post, El Paso Times, Huffington Post, KFOX14, LSE blog, Mexico News Daily, Nacla, NBC News, New York Times, Telegraph, Texas Tribune, The Guardian, The Sun, USA Today, Washington Post.
} 
Lektorált tanulmányok

A központi témakör, amelyről az utazási bejegyzések szólnak, és amire az online hírek és elemzések minduntalan visszatérnek, a város közbiztonsága. Ez a kérdés a pápalátogatás tényétől függetlenül is felmerül, azaz elsődlegesen ez határozza meg a hely megítélését.

Amennyiben azokból a tényekból indulunk ki, amelyeket a médiahírek hivatkoznak, akkor Juarez városában a gyilkosságok és egyéb erőszakos cselekmények száma folyamatos csökkenést mutatott 2016. év elejéig. Ezt a pozitív trendet mintegy megkoronázta a pápalátogatás, amely bár erőteljesen szólt a helyi és általában a mexikói problémákról, pozitív és reményteli jövőképet rajzolt fel. Ahogy egy helyi üzletember nyilatkozta: „Ez egy nagyszerú lehetőség számunkra. Megmutathatjuk, hogy többek vagyunk, mint a gyilkosságok, emberrablások és túzharcok".

A közbiztonság megítélésében bizakodóak a pápalátogatás kapcsán megjelent hírek. Bár rendszeresen megemlítik a város rossz hírnevét és veszélyes múltját, mind a javuló helyzetról szólnak, illetve arról, hogy esély és igény van a változásra. Amennyiben a pápalátogatást követó idószakra tekintünk - különösen a közelmúltra - akkor kiderül, hogy ezek a remények nem váltak valóra, ső́t a közbiztonság tekintetében visszaesés következett be. 2016 végétól újabb erôszakhullámról számolnak be a hírek, majd 2018 első felében a nókkel szembeni erőszak kérdése kerül előtérbe. A megjelent hírek szerint Juarez továbbra is veszélyes és erôszakkal teli város.

A média negatív híradása az utazási portálokon is megjelenik. A Juarez város biztonságát firtató kérdésekre személyes tapasztalat és hallomás alapján egyaránt érkeztek reakciók. Azok, akik nem a személyes élményeiket hivatkozzák, mindinkább veszélyes helynek minôsítik a várost, míg a személyes tapasztalattal bírók körében vegyesebb a kép. A virtuális beszélgetésekhez hozzászóló Juarezben éló lakosok szerint a város biztonságos, míg a látogatók egy része a biztonságos, más része a veszélyes véleményt osztja. Utóbbiak esetében hangsúlyosan jelenik meg, hogy bizonyos részeket egyértelmúen el kell kerülni, illetve jobb a forgalmasabb részeken maradni és a városlátogatást nappalra tenni. Egyikük ajánlása szerint „Ne Juarez legyen az elsô mexikói város, amit meglátogatsz. Kezdd egy biztonságosabb helyen."

Azok, akik a várost biztonságosnak érzik, kiemelik milyen jól érezték magukat, úgymint jót ettek, vásároltak, szórakoztak. Igaz, náluk is megjelent az óvatosság, és eleinte tartottak attól, hogy mit találnak majd Juarezben.

Összességében elmondható, hogy a gyenge közbiztonság és az erôszakosság képe jelenti az elsô asszociációt Juarezre, amely saját tapasztalat alapján felülíródhat, de még ekkor is óvatossággal kísérve.
Az utazási oldalak hozzászólásai alapján egy olyan kép rajzolódik ki a városról, amelynek nincs turisztikai értéke, ha mégis, az legfeljebb a vásárlásban (például olcsó gyógyszerbeszerzés) és az étkezési lehetóségekben merül ki. A pozitív említések az emberek kedvességéról és vendégszeretetérôl szóltak, de ezek nem tudták felülírni a közbiztonsággal szembeni félelmeket. Itt érdemes megemlíteni, hogy a pápalátogatás ténye és jelentése nem merült fel ezekben a beszélgetésekben.

\subsubsection{A pápalátogatás időszakának hírei}

A pápalátogatással összefüggésben megjelent hírek hangvétele pozitív vagy semleges (értékelô, kiegyensúlyozott). Az eseményeket bemutató hírek és beszámolók lelkes emberekrôl, áhítatról és meghatódottságról szóltak, valamint megemlítették, hogy erőszakos búncselekmény egyáltalán nem történt a látogatás ideje alatt.

A pápalátogatás Juarezre irányította a figyelmet, hiszen olyan globális médiumok is foglalkoztak az eseménnyel, mint a New York Times, a BBC és a Guardian. Igaz, ezek a hírek Juarezt a mexikói problémák (úgymint búnözés és erôszak) példájaként tárgyalták. Sokszor általánosságban mutatták be a régió problémáit, és távolságtartó politikai értékelést adtak közre. Hangsúlyt kapott bennük a pápa személye és az általa felvállalt ügyek, beleértve a migráció aktuális és égető kérdését. Ezekből a hírekből kevés szólt magáról Juarez városáról, elsődlegesen a pápalátogatás helyszíneként utaltak rá. Pozitív ugyanakkor, hogy a leközölt gazdag fotóanyagban Juarez több városrésze is feltúnt, hozzájárulva ezzel a város felismerhetóségéhez, ezáltal márkaértékéhez.

Ennek az idôszaknak a hírei sokszor pozitív kicsengésúek, említik a városban történt fejlesztéseket, a javuló közbiztonságot és a látogatást kísérô pezsgő városi életet. A Guardian tudósítója szerint: „Juarez nemcsak biztonságosabb lett, de fejlődik is: uj éttermek, új autószalonok és más üzletek indultak el".

\subsubsection{Mire jó a pápalátogatás?}

A pápalátogatás jelentőségét egyöntetúen elismerik a médiaközlések, de a hasznosság és tartósság megítélése vegyes a város szempontjából. A pozitív említések a lehetőséget hangsúlyozzák, illetve kiemelik a médiafigyelmet és a kedvező fényt, amelyet a városra vetít. Az ellentábor szerint a látogatás csak elfedi a valóságot, politikai és imázsjavítási céljai vannak, valamint felrója a költségek mértékét, amivel a rendezvény megszervezése járt. A pozitív és negatív vélemények listáját lásd a 2. táblázatban. 
2. táblázat A pápalátogatás pozitív és negatív értelmezései

\begin{tabular}{|l|l|}
\hline \multicolumn{2}{|c|}{ A pápalátogatás... } \\
\hline $\begin{array}{l}\text { tanúsítja, hogy a hely } \\
\text { már nem veszélyes }\end{array}$ & elfedi a problémákat \\
\hline esély a változásra & politikai eszköz \\
\hline $\begin{array}{l}\text { más fényben mutatja } \\
\text { a várost }\end{array}$ & imázsjavitás mindössze \\
\hline $\begin{array}{l}\text { felpörgeti a kereskedelmet és } \\
\text { a turizmust }\end{array}$ & túl költséges esemény \\
\hline $\begin{array}{l}\text { nyilvánosságot, } \\
\text { pozitív hírt ad }\end{array}$ & nincs hosszútávú jelentósége \\
\hline $\begin{array}{l}\text { pozitív történet } \\
\text { a város életében }\end{array}$ & \\
\hline
\end{tabular}

Forrás: saját szerkesztés

A pápalátogatást övező várakozások közepette mind a meginterjúvolt lakosság, mind a város képviselői megemlítették, hogy Ferenc pápa nem „Varázspálcával érkezik”, hogy minden problémát azonnal megszüntessen. Ugyanakkor a látogatás összefogást hozott, pozitív érzéseket keltett, és megerôsítette az elkötelezettséget a változás iránt. Ezt hangsúlyozza az a tény is, hogy az esemény egyéves évfordulójára a pápalátogatás emlékét felidézendó és megerősítendő szobrot emeltek. Az új szobor egyúttal új látványosságként és emblematikus - felkeresendő - helyként szolgálhat a várost meglátogató turisták számára.

Az esemény kettősségét jól fejezi ki egy helyi lakos véleménye, aki szerint "a látogatás csodálatos volt, de aztán az erôszak újra felerôsödött... a látogatás idejére elfedték a dolgokat, de aztán minden visszaállt a megszokott mederbe".

\section{Zárszó}

Ahogy ANTTIROIKO (2015) megállapította, a városmárkázás nagy része "a média színterén zajlik”, miközben „a város irányításának csak elenyészô kontrollja van a márka felett". Amennyiben az esemény médiajelenlétét nézzük, a látogatásnak hatalmas visszhangja volt globális érdeklődés közepette. A kiválasztott öt helyszínnek köszönhetően láthatóvá váltak a város emblematikus helyszínei, amelyek építhetik, illetve megerősíthetik a városképet az érintettek körében. Ráadásul a pápalátogatás idején a médiahírek nem az erőszakról és a problémákról, hanem elsősorban a felfokozott érzelmekről, az örömról szóltak, és ennek tükrében mutatták meg Juarezt.

Az elméleti háttérben bemutatott városmárkahatszög szerint a pápalátogatás érintheti a város ismertségét, megítélését, érdekességét és fizikai jel- lemzőit egyaránt. A média által közvetített pozitív kép és a helyszínre látogatók (mind helyi lakosok, mind turisták) tapasztalatai megváltoztathatják egy hely megítélését. A város érdekesebb hellyé válhatott a pápalátogatás helyszínei és a létrejött új attrakciók révén. Utóbbira példa a látogatásnak emléket állító új szobor, amely a készítője szerint nemcsak mementója a meghatározó eseménynek, hanem "szimbóluma a reménynek és a pozitív változásnak" (EL PASO TIMES 2016a). A hely jellemzőit, fizikai megjelenését érintik azok a fejlesztések, többek között a papneveló intézet felújítása, amelyek a látogatást kísérték (EL PASO TIMES 2016b).

Elemzésünk szerint Ferenc pápa jelenléte és üzenetei katalizátorként szolgálhattak volna Juarez város kedvezőbb megítéléséhez, ugyanakkor önmagában ennek az egy eseménynek a hosszútávú pozitív hatása megkérdőjelezhető a mélyben meghúzódó strukturális problémák miatt, amelyek Mexikó más városait is érintik, úgymint a migráció és a gyenge közbiztonság. Ezzel együtt a látogatás egyértelmú érdeme, hogy meg tudta mutatni a város jó oldalát, szívélyes lakóit és vendégszeretetét. A látogatók meggyőződhettek arról, hogy Juarez több, mint egy erőszakossággal teli ipari város, hiszen láthatóvá váltak közösségi terei és szórakozási lehetóségei is. Mindez jó alapja - de csak alapja - lehet egy tudatos, az összes érintettet figyelembe vevő és bevonó városmarketing stratégiának. Összességében elmondható, hogy annak ellenére, hogy egy nagyszabású rendezvény szimbolikus üzenete jól illeszkedik a városmarketing céljaihoz, valamint a helyi érintettek körében magas az elfogadottsága, nem elegendő a tartós változás eléréséhez. Juarez esetében egy ideig úgy túnt, hogy a rossz imázs alapjául szolgáló problémák megoldódnak, és a városra vonatkozó észlelésekben is ezt a fejlődést kell megváltoztatni, lekövetni. A valóságban azonban a problémák megmaradtak, így az imázsjavítást célzó tevékenységek - függetlenül azok jóságától - nem lehettek sikeresek.

A pápalátogatás és lehetséges következményei összehasonlíthatóak más mega eseményekkel, úgymint az olimpiai játékok megrendezése. Fontos különbség azonban - amely jelen cikk újdonságértékét is adja - hogy ezek mind legitimációs bázisukban, mind a helyi lakossági elfogadás tekintetében eltérnek. Amíg az olimpiai játékok esetében felmerülhet, hogy miért szükséges minden alkalommal más helyszínen kiépíteni a teljes infrastruktúrát (GOLD-GOLD 2008), addig ez a kérdés a pápalátogatásnál nem jelenik meg. Ugyanígy, míg a nagy sportrendezvények megrendezését sokszor erôs helyi ellenérzés kíséri, a pápalátogatások esetében ez kismértékú. Ezzel együtt jelen elemzés eredményei városimázs 
szempontjából részben hasonlítanak a nagy sportesemények megítélésére vonatkozó kutatások eredményeihez. Reputáció tekintetében ezeket a rendezvényeket jellemzően pozitív várakozások előzik meg (MÜLLER 2012), míg a hosszútávú hatás általában limitált (lásd például ZHANGZHAO 2009). A háttérben álló okok azonban, a fentiek szerint részben eltérnek.

A hazai települések számára jó irányvonalként szolgálhat annak az összefüggésnek a felismerése, miszerint a városimázs-építés nemcsak egy kifelé irányuló folyamat, lévén, hogy imázsépítési szempontból ugyanolyan fontos az, hogy valójában mit is gondolnak saját településükról az ott élók. Ebben nagy jelentôsége van a fentebb említett, általában a sportrendezvények kapcsán felmerüló helyi ellenérzésnek, ami egy széleskörben elfogadott vallási esemény esetén csekélyebb mértékben jelentkezik. Tehát amennyiben egy településnek integrált - mind az oda érkezóket, mind pedig az ott élőket megcélzó - városimázs-építési szándékai vannak, célszerú olyan események szervezésére és kommunikálására fektetni a hangsúlyt, amelyek elfogadottabbak a helyi közösségben (úgymint a meghatározó vallási események).

Jelen elemzés korlátját jelenti a vizsgált dokumentumok köre. A nyelvi korlát - angol nyelvú források áttekintése - csak a nemzetközi (vagy annak szánt) híreket és turisztikai bejegyzéseket érintette, így a lokális kép megismerésére korlátozottan volt alkalmas. Ugyanilyen korlát az online forráselemzés, amely publikus anyagokra terjedt $\mathrm{ki}$, és nélkülöznie kellett a helyi érintettektől származó adatokat, elemzéseket. További kutatási lehetőséget jelent a negatív városimázs megfordításának mélyebb megértése, valamint az események imázsformáló jelentőségén belül a kisebb és nagyobb helyi támogatottsággal, valamit az eltéró szimbolikus üzenettel bíró események vizsgálata.

\section{Felhasznált irodalom}

ANHOLT, S. (2006): The Anholt-GMI city brands index: How the world sees the world's cities. Place branding. 2(1). pp. 18-31.

ASHWORTH, G. J. - VOOGD, H. (1990): Selling the city: Marketing approaches in public sector urban planning. Belhaven Press: London.

BRAUN, E. - ZENKER, S. - KAVARATZIS, M. (2013): My city - My brand: The different roles of residents in place branding. Journal of Place Management and Development. 6(1). pp. $18-28$.

DURAN, R. D. (2014): Elaboración del duelo de una madre cuyo hijo trabajaba como sicario en Ciudad Juárez, Chihuahua. Nóesis: Revista de Ciencias Sociales y Humanidades. 23(46). pp. 224-245.

FAN, Y. (2006): Branding the nation: What is being branded? Journal of Vacation Marketing. 12(1). pp. 5-14.

FLORIDA, R. (2014): The Rise of the Creative Class: And How It's Transforming Work, Leisure, Community, and Everyday Life. Brilliance Audio, Unabridged edition.

GOLD, J. R. - GOLD, M. M. (2008): Olympic cities: regeneration, city rebranding and changing urban agendas. Geography compass. 2(1). pp. 300-318.

GREENBERG, M. (2000): Branding cities: A social history of the Urban Lifestyle Magazine. Urban affairs review. 36(2). pp. 228-263.

GYÓRI, E. B. (1998): Az ország megítélése külföldi szemmel. Marketing és Menedzsment. 32(3). pp. 47-52.

HERSTEIN, R. - BERGER, R. - JAFFE, E. (2013): Five typical city branding mistakes: Why cities tend to fail in implementation of rebranding strategies. Journal of brand strategy. 2(4). pp. 392-402.

HOSPERS, G. J. (2010): Making sense of place: from cold to warm city marketing. Journal of place and management. 3(3). pp. 182-193.

KAVARATZIS, M. (2007): City Marketing: The Past, the Present and Some Unresolved Issues. Geography Compass. 1(3). pp. 695-712.

KAVARATZIS, M. - ASHWORTH, G. (2005): City branding: An effective assertion of identity or a transitory marketing trick? Economische en Sociale Geografie. 96(5). pp. 506-514.

KOTLER, P. (2002): Marketingmenedzsment. KJKKerszöv, Budapest. p. 39.

MOLNÁR-CSOMÓS, I. (2017): Országimázs-épités Magyarországon. MSc szakdolgozat. Budapesti Gazdasági Egyetem, Budapest. p. 13.

MÜLLER, M. (2012): Popular perception of urban transformation through megaevents: understanding support for the 2014 Winter Olympics in Sochi. Environment and Planning C: Politics and Space. 30(4). pp. 693-711.

OLINS, W. (2002) Branding the nation - The historical context. Journal of Brand Management. 9(4/5). pp. 241-248.

OOI, C.-S. (2013): Why are cities becoming alike when each city is branded as different? CLCS Working Paper Series. Copenhagen Business School. pp. 1-18.

PAPP-VÁRY, Á. (2006): Az országmárkázás elmélete és gyakorlata. rekláMérték. Kommunikációelméleti szaklap. 4(34). pp. 1-11.

PAPP-VÁRY, Á. (2011): The Anholt-GMI city brand hexagon and the Saffron European City Brand 
barometer: A comparative study. Regional and Business Studies. 3(1). pp. 555-562.

PISKÓTI, I. (2012): Régió- és településmarketing - Marketingorientált fejlesztés, márkázás. Akadémiai Kiadó Zrt, Budapest.

RAMOS, M. J. (2011): La marca ciudad y el uso de la web 2.0 como filtro de la realidad y prevención de una crisis (City Branding and Web 2.0, the reality and its prevention in crisis circumnstances). Razon y palabra, Semiótica y comunicologia: Historias y propuestas de una mirada científica en construcción. 72. pp. 1-26.

RICHARDS, G. - WILSON, J. (2004): The impact of cultural events on city image: Rotterdam, cultural capital of Europe 2001. Urban studies. 41(10). pp. 1931-1951.

RIEZEBOS, R. (2009): City Branding, sense or nonsense? White Paper of the European Institute for Brand Management, European Institute for Brand Management: Rotterdam.

SCHEEL, C. - PINEDA, L. (2014): Innovacities. Monterrey: UTADEO.

SARTORI, A. - MOTTIRONI, C. - CORIGLIANO, M. A. (2012): Tourist destination brand equity and internal stakeholders: An empirical research. Journal of Vacation Marketing. 18(4). pp. 327-340.

ZHANG, L. - ZHAO, S. X. (2009): City branding and the Olympic effect: A case study of Beijing. Cities. 26(5). pp. 245-254.

\section{Internetes források}

ACI PRENSA VATICANA (2016): Discursos del viaje apostolico a Mexico en Febrero 2016 (Speeches from Pastoral trip to Mexico in February, 2016). https://www.aciprensa.com/ noticias/todos-los-discursos-homilias-y-mensajes-del-papa-francisco-en-mexico-53969, Letöltve: 2017. augusztus 1.

ANTTIROIKO, A.-V. (2015): Interview with AriVeikko Anttiroiko on City Branding as Strategic Management Tool for Local Governments. The Place Brand Observer. http://placebrandobserver.com/ari-veikko-anttiroiko-city-branding/, Letöltve: 2017. augusztus 1.

CBC (2018): Calgarians don't want to host Olympics, according to poll. https://www.cbc.ca/news/canada/calgary/calgary-olympic-2026-poll-cbc-calgary-1.4894146, Letöltve: 2019. január 24.
EL PASO TIMES (2016a): Statue of Pope Francis being built in honor of visit. https:// eu.elpasotimes.com/story/news/local/juarez/ pope/2016/02/01/statue-pope-francis-beingbuilt-honor-visit/79666000/, Letöltve: 2018. szeptember 28.

EL PASO TIMES (2016b): Juárez seminary readies for Pope Francis' visit. https://eu.elpasotimes.com/ story/news/local/juarez/2016/01/07/juarezseminary-readies-pope-francis-visit/78437090/, Letöltve: 2018. szeptember 28.

HOJE-TAASTRUPP KOMMUNE (2010): Creative City Challenge: A branding framework. The Interreg IVB North Sea Region Programme. pp. 4. http://archive.northsearegion. eu/files/repository/20100816173849_A Branding_Framework.pdf, Letöltve: 2017. augusztus 10.

IPSOS MORI (2010): Papal Visit Poll. https://www. ipsos.com/ipsos-mori/en-uk/papal-visit-poll, Letöltve: 2019. január 24.

MARTÍNEZ, A. (2004): Planificación estratégica y la imagen de la ciudad. (Strategic planning and city's image). I Congreso Citymarketing Elche 2004, Elche. http://www.ciudadreal.es/ planestrategico/Planif_estr_e_imagen_ciudad_ Elche.pdf, Letöltve: 2019. január 24.

NEW YORK TIMES (2016): Poll Finds Strong Opposition Among Brazilians to Rio Games. https://www.nytimes.com/2016/07/20/sports/ olympics/poll-finds-strong-opposition-amongbrazilians-to-rio-games.html, Letöltve: 2019. január 24.

PLAN ESTRATÉGICO DE CIUDAD JUÁREZ (2016): Informe Así Estamos Juarez 2016 (We are Juarez 2016). Ciudad Juárez: Plan estratégico de Ciudad Juárez. https://planjuarez.org/wpcontent/uploads/2018/12/informe_AEJ_2016. pdf, Letöltve: 2019. január 24.

REYNOLDS, T. (2011): The rise and fall of native communities at the Old El Paso del Norte Mission. http://www.donaanacountyhistsoc.org/ HistoricalReview/2011/HistoricalReview2011. htm, Letöltve: 2017. augusztus 15.

VAN GELDER, S. (2008): An introduction to city branding. Placebrands Ltd. pp. 1. https:// www.zukunft-metropole.at/Downloads/An Introduction_to_City_Branding_Sicco_van Gelder.pdf, Letöltve: 2017. augusztus 15. 